\title{
AVIFAUNA STRUCTURE OF BOREAL ZONE OPEN HABITATS (ISHIM PLAIN, WESTERN SIBERIA)
}

\author{
STEPAN BOLDYREV ${ }^{1}$, ALENA LEVYKH $\otimes^{2}$, NADEZHDA GANZHERLI ${ }^{3}$, SERGEY GASHEV $^{4}$, NATALYA SOROKINA ${ }^{4}$ \\ ${ }^{1}$ Department of Biology, Geography and Methods of Teaching, Ishim P.P. Ershov Teachers Training Institute (branch) of Tyumen State University, 1, Lenin str., \\ Ishim 627750, Russian Federation; e-mail: boldyrev.stepan@yandex.ru \\ ${ }^{2}$ Chemical Analysis Research Laboratory, Environmental Sector, Arctic Research Center, 20, Respubliki str., Salekhard 629008, Russian Federation; e-mail: \\ aljurlev@mail.ru \\ ${ }_{3}^{3}$ Department of English Philology and Translation, Tyumen State University, 6, Volodarskogo str., Tyumen 625003, Russian Federation; e-mail: n.v.ganzherli@utmn.ru \\ ${ }^{4}$ Department of Zoology and Evolutionary Ecology of Animals, Institute of Biology, Tyumen State University, 6, Volodarskogo str., Tyumen 625003, Russian \\ Federation; e-mail: gsn-61@mail.ru, natalya_sorokina@rambler.ru
}

$\bowtie$ Corresponding author

Received: 16 September 2020 / Accepted: 8 December 2020

Abstract

Boldyrev S., Levykh A., Ganzherli N., Gashev S., Sorokina N.: Avifauna structure of boreal zone open habitats (Ishim plain, western Siberia). Ekológia (Bratislava), Vol. 40, No. 3, p. 258-266, 2021.

\begin{abstract}
In 2014-2016 field seasons, bird censuses were conducted on 34 flyways in seven different types of open habitats of the Russian part of the Ishim River region. Ninety-five species from 72 genera from 10 orders were registered. It is established that the taxonomic composition and ecological structure of avifauna of the habitats under investigation comply with their biotopical characteristics; diversity of taxons and ecological groups show positive correlation with habitats' heterogeneity. In natural habitats, the maximum total abundance of birds, highest species diversity within the habitat ( $\alpha$-diversity) and species sustainability are characteristic of river meadows ornithocenoses, mainly due to low-numbered species and a higher evenness index. In disturbed habitats, the maximum total abundance, species diversity, Shannon diversity index, Pielou's evenness index, minimal index of diversity and highest indices of elastic and general sustainability are characteristic of abandoned fields ornithocenoses, due to a more complex structure of vegetation communities and habitat resource capacity, which increased in the course of secondary succession. Due to natural and historical unity, middle and northern forest steppe's avifaunae are most similar. The southern taiga open habitats' ornithocenoses are most heterogeneous, due to an increased amount of dendrophilous birds along with forest habitats' increased area and diversity.
\end{abstract}

Key words: avifauna, ornithocenosis, Ishim River region, open habitats, species diversity, natural-climatic zones.

\section{Introduction}

Most of the territory of the Russian Ishim River region is situated on the Ishim plain, within Tobolsk-Ishim forest steppe of Western Siberia. This territory comprises forest-steppe landscapes, the majority of which are interspersed birch and birch-and-asp forests and outliers, salt and solonetz meadows, anthropogenically transformed meadow steppes and steppificated meadows (Soloviev et al., 2016). In the North, a significant portion of the Russian Ishim River region features subtaiga and southern taiga forest ranges with such areas as flood plain meadows, transformed meadows, abandoned fields and farming fields.

Historically, the forest steppe has always been the most populous area and, consequently, subject to more profound anthropogenic transformation (Mordkovich, 2012). Natural meadow and meadow-steppe landscapes of Tobolsk-Ishim forest steppe had been transformed by the beginning of the 19th century (Ruzskij, 1897; Soloviev, 2012). At the same time, among all types of foreststeppe zone habitats, it is the area of open habitats that is most affected by anthropogenic activities. Researches held in Great Britain and continental Western Europe show that birds' diversity in agrophytocenoses tends to go down (Donald et al., 2001; Kamp et al., 2016b; Pain, Pienkowski, 1996). Researches into open habitats avifaunae in Northern and Central Kazakhstan in anthropogenic load gradient show that there is deterioration in bird species composition and decline in bird species diversity (Brinkert et al., 2016; Kamp et al., 2016a). Although the causes of decline of many bird species are not fully explicable (Bradbury et al., 2003), ornithologists consider farming intensification to be the main cause of global decline in the diversity of open habitats bird species (Allan et al., 2015).

At the same time, the forest-steppe zone of Western Siberia remains understudied as a biome and as a biodiversity reserve (Mordkovich, 2012). This fact motivates topicality and the objective of the current article: the study of taxonomic and ecological structure, species diversity and sustainability of natural and transformed ornithocenoses of open habitats of the Russian Ishim River region in different subzones of forest steppe and territories adjacent to it.

(c) The Author(s) 2021. This is an open access article distributed under the terms of the CC BY-NC-ND license.

https://content.sciendo.com/view/journals/eko/eko-overview.xml 
Table 1. Pilot areas and routes.

\begin{tabular}{|l|c|c|c|c|c|c|c|}
\hline № & $\mathbf{1}$ & $\mathbf{2}$ & $\mathbf{3}$ & $\mathbf{4}$ & $\mathbf{5}$ & $\mathbf{6}$ & $\mathbf{7}$ \\
\hline Latitude & 55.58592 & 55.72232 & 55.96296 & 56.12641 & 56.27917 & 56.4979 & 57.20177 \\
\hline Longitude & 70.49085 & 68.97785 & 69.59567 & 69.82961 & 69.97685 & 70.86306 & 70.64746 \\
\hline Natural subzone & MFS & MFS & NFS & NFS & NFS & SbT & ST \\
\hline Pilot area, km & 12 & 8 & 14 & 12 & 16 & 8 & 10 \\
\hline Number of/length of routes, km & $6 / 11.3$ & $3 / 12$ & $4 / 12$ & $4 / 12$ & $7 / 21$ & $4 / 8$ & $6 / 10$ \\
\hline Marshy meadows & + & & & + & + & & + \\
\hline Meadows with groves & + & + & + & + & + & + & + \\
\hline River meadows & + & & & & + & + & + \\
\hline Abandoned fields & + & & & + & + & & + \\
\hline Salt meadows & + & & + & & + & + & + \\
\hline Pastures & + & + & & + & & + \\
\hline Fields & + & + & + & + & + & + \\
\hline
\end{tabular}

Notes: MFS - middle forest steppe; NFS - northern forest steppe; SbT - subtaiga; ST - southern taiga; 1 - marshy meadows; 2 - meadows with groves; 3 - river meadows; 4 - abandoned fields; 5 - salt meadows; 6 - pastures; 7 - fields.

Table 2. Indices of species richness, diversity and sustainability of ornithocenoses of Ishim River region open habitats.

\begin{tabular}{|c|c|c|c|c|c|c|c|}
\hline & $\begin{array}{c}\text { Marshy } \\
\text { meadows }\end{array}$ & $\begin{array}{c}\text { Meadows with } \\
\text { groves }\end{array}$ & River meadows & $\begin{array}{c}\text { Abandoned } \\
\text { fields }\end{array}$ & Salt meadows & Pastures & Fields \\
\hline $\mathbf{n}$ & 12 & 18 & 17 & 16 & 12 & 26 & 29 \\
\hline P & $1767.1 \pm 31.91$ & $1682.4 \pm 34.11$ & $2186.3 \pm 34.7$ & $1807.2 \pm 30.92$ & $1392.0 \pm 20.03$ & $809.6 \pm 17.26$ & $238.5 \pm 15.5$ \\
\hline $\mathbf{R}$ & $76.59 \pm 22.56$ & $70.41 \pm 15.78$ & $80.83 \pm 17.75$ & $90.77 \pm 23.45$ & $75.81 \pm 14.94$ & $44.96 \pm 15.92$ & $43.69 \pm 10.48$ \\
\hline H & $4.15 \pm 0.18$ & $4.09 \pm 0.79$ & $4.47 \pm 0.39$ & $3.77 \pm 0.58$ & $4.34 \pm 2.65$ & $3.10 \pm 0.46$ & $1.50 \pm 0.51$ \\
\hline D & $1.83 \pm 0.45$ & $1.33 \pm 0.15$ & $1.44 \pm 0.02$ & $1.21 \pm 0.03$ & $0.79 \pm 0.03$ & $5.51 \pm 0.08$ & $0.93 \pm 0.03$ \\
\hline C & $0.92 \pm 0.04$ & $0.89 \pm 0.89$ & $0.75 \pm 0.62$ & $0.20 \pm 0.07$ & $0.50 \pm 0.09$ & $0.51 \pm 0.08$ & $0.85 \pm 0.71$ \\
\hline E & $0.72 \pm 0.03$ & $0.74 \pm 0.05$ & $0.95 \pm 0.40$ & $0.70 \pm 0.05$ & $0.50 \pm 0.03$ & $0.57 \pm 0.05$ & $0.20 \pm 0.04$ \\
\hline Ur & $0.06 \pm 0.01$ & $0.23 \pm 0.04$ & $1.08 \pm 0.43$ & $0.35 \pm 0.10$ & $0.25 \pm 0.05$ & $0.70 \pm 0.06$ & $0.60 \pm 0.12$ \\
\hline Uu & $0.93 \pm 0.05$ & $0.11 \pm 0.05$ & $6.20 \pm 1.70$ & $0.54 \pm 0.14$ & $0.52 \pm 0.05$ & $0.56 \pm 0.08$ & $0.26 \pm 0.10$ \\
\hline $\mathbf{U}$ & $0.99 \pm 0.06$ & $0.34 \pm 0.15$ & $7.30 \pm 1.71$ & $0.89 \pm 0.40$ & $0.77 \pm 0.20$ & $1.48 \pm 0.25$ & $0.86 \pm 0.20$ \\
\hline
\end{tabular}

Notes: $\mathrm{n}$ - number of observation sessions; $\mathrm{P}$ - mean abundance sp. $/ \mathrm{km}^{2} ; \mathrm{R}$ - Margalef species richness index; $\mathrm{D}$ - Simpson's diversity index; $\mathrm{H}$ - Shannon diversity index; E - Pielou's evenness index; C - Simpson's dominance index; Ur - resistant sustainability index; Uu - resilient sustainability index; U - overall sustainability index.

\section{Material and methods}

The bird censuses were conducted in the 2014-2017 field seasons on the territory of seven districts of the Tyumen Region (Abatsk, Berdyuzhye, Vikulovo, Ishim, Kazanskoye, Sladkovo, Sorokino districts) and Ust'-Ishim district of the Omsk Region, Russia. All these districts are situated in catchment and watershed areas of the Ishim River and its tributaries. For this purpose, the authors defined seven key plots, and their total area exceeds $72 \mathrm{~km}^{2}$ (Table 1). There are seven types of habitats there: marshy meadows, meadows with groves, river meadows, abandoned fields, salt meadows, grazing meadows (or pastures) and fields. The censuses were carried out with unlimited width of the transect (Ravkin, 1967; Ravkin et al., 2016), as modified by Gashev (2014). At each of the habitats under study, there was a fixed route of $3.1-4 \mathrm{~km}$ long. There were at least three observation sessions a field season per route. The results of all observations at a given habitat were averaged. Table 2 shows the number of observations.
Dominance diversity curve and diversity indices were used in order to establish structural peculiarities of avifauna of the plots under investigation. Using the number of species and abundance of individuals of each species, the following a-diversity indices were calculated: Margalef species richness index $(R)$, Simpson's diversity index $(D)$, Shannon diversity in$\operatorname{dex}(H)$, Pielou evenness index $(E)$, Simpson's dominance in$\operatorname{dex}(C)$, as well as indices of resistant $(U R)$, elastic $(U U)$ and general sustainability $(U)$ (Gashev, 2000, 2001, 2012; Blinkova, Shupova, 2017). These latter make use of diversity indices and respective weights of physic and geographic peculiarities of a natural zone and its succession stage. We follow Gashev's (2000) understanding of resistant, elastic and general sustainability indices (for more detail on them, Levykh, Panin, 2019). We used the following $K$ and $G$ values: for the southern taiga subzone 5.0 and 0.60 , respectively; subtaiga 5.5 and 0.55 ; northern forest steppe 6.0 and 0.50 ; and middle forest steppe 5.8 and 0.53 (Gashev, 2000, 2001; Gashev et al., 2015). 
A
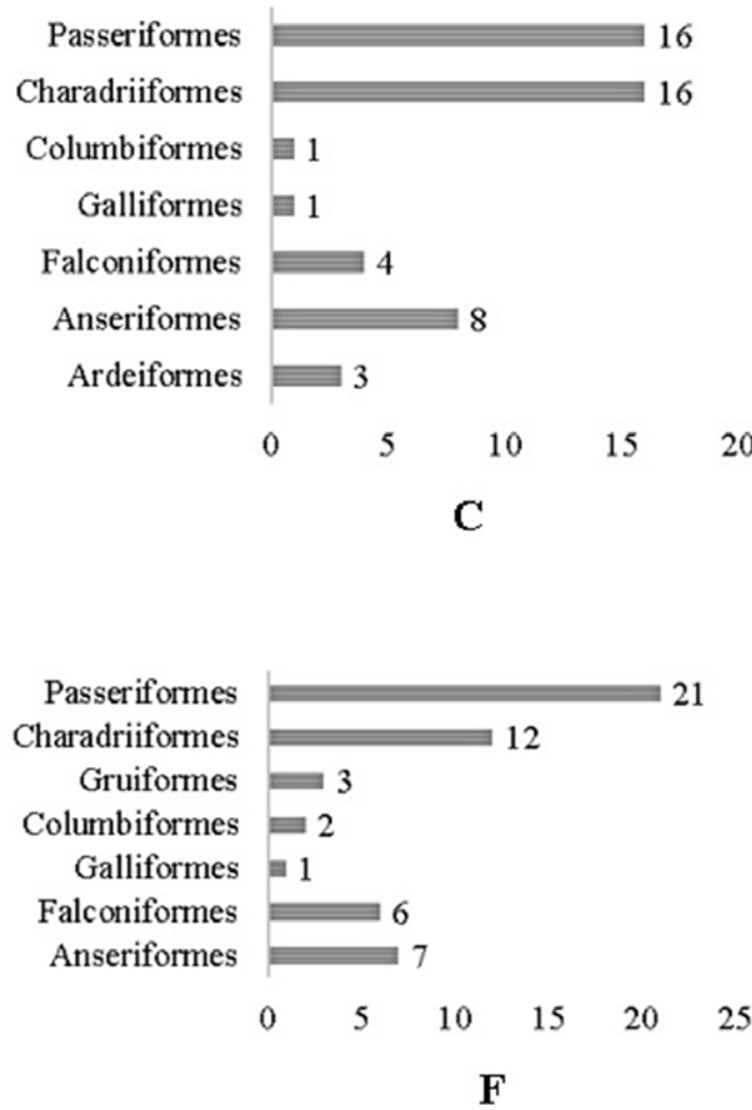

B

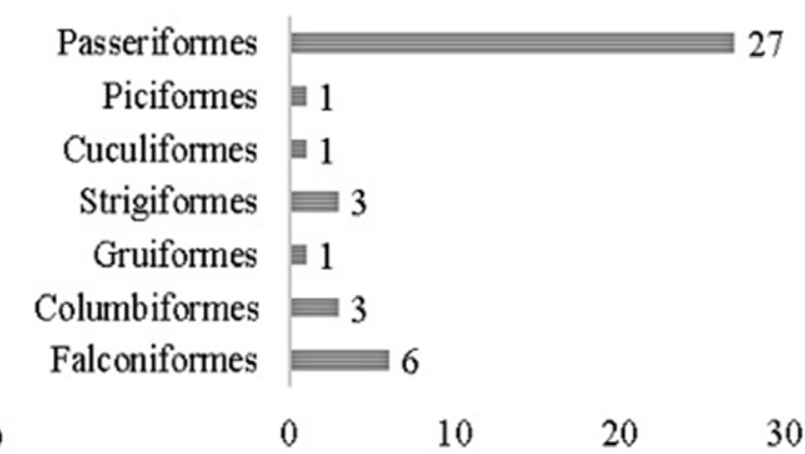

D

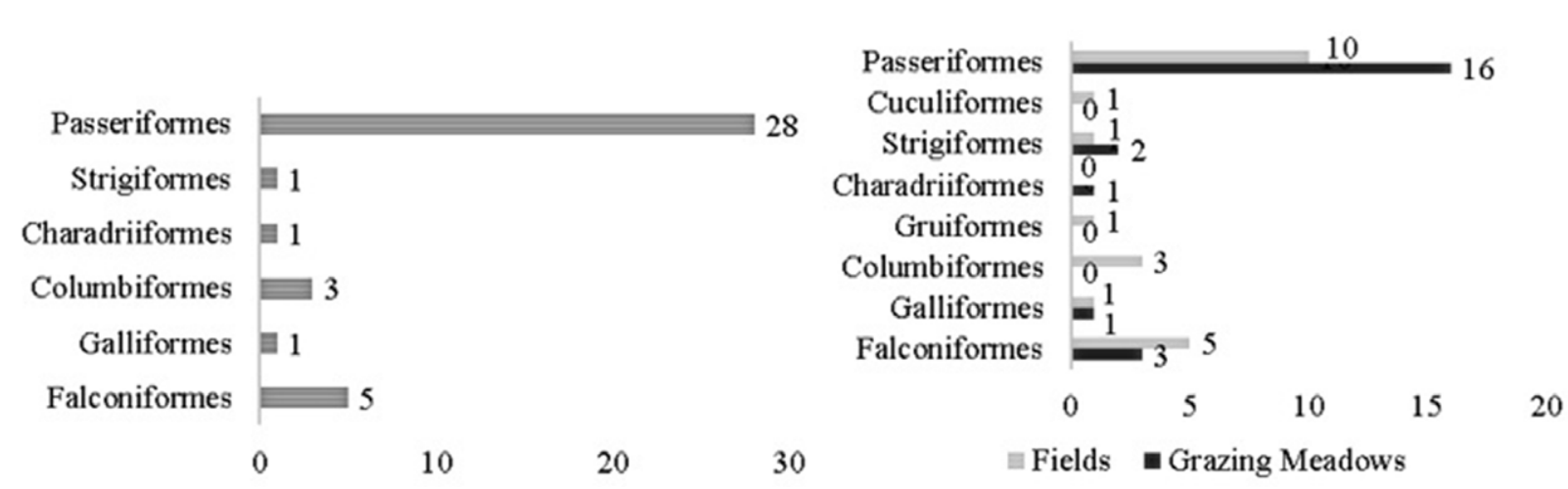

Fig. 1. The taxonomic structure of Ishim River region open habitats' avifauna, Russian part: A - marshy meadows; B - meadows with groves; $\mathrm{C}$ - river meadows; D - abandoned fields; F - salt meadows; G - grazing meadows and fields.

Arithmetical mean values of abundance $\left(\right.$ specimen $\left./ \mathrm{km}^{2}\right)$, diversity and sustainability indices were calculated for each study area. Between-sample statistic comparisons were performed with the help of Student t-test.

Jaccard index (Ij) (Jaccard, 1901) was used to estimate similarity and diversity of avifaunae of different habitats. Whittaker differentiation index (Iw) (Whittaker, 1964) was calculated to analyse differentiating diversity between the communities of different natural zones (subzones). The authors used the bird names as listed in Stepanyan (2003).

\section{Results}

Over the period of the research, there were 95 species of birds from 72 genera, 11 orders registered in all types of open habitats (Fig. 1). In terms of the number of species, Passeriformes order predominates in all types of habitats. A significant amount of birds in marshy meadows, meadows with groves and abandoned fields come from Charadriformes order; in river, salt and grazing meadows - from Anseriformes order. When going from the subzone of the middle forest steppe to the northern forest steppe, 
the number of registered species slightly increases from 70 to 72 , respectively, and then decreases in subtaiga (54) and southern taiga (48). The maximum number of species was registered at the abandoned fields (58), slightly less at the river meadows (52) and marshy meadows (49); the minimum - at the fields (22) and grazing meadows (23).

In the bird population of all the studied habitats, the lowand ground-nesting birds prevail (Fig. 2a); among these, there are such common species (with more than $1 \mathrm{sp} . / \mathrm{km}^{2}$ ): Alauda arvensis L., 1758, Coturnix coturnix L., 1758, Crex crex L., 1758, Limosa limosa L., 1758, Motacilla citreola Pallas, 1776, M. flava L., 1758, Saxicola ruberta L., 1758, S. torquata L., 1766, Tringa totanus L., 1758, Vanellus vanellus L., 1758.

In all the studied habitats, dendrophilous species subdominate. These are high- and mid-canopy nesting birds, and their number depends greatly on the type of their habitat (from 11 in the fields up to 28 in the abandoned fields). In terms of abundance, a part of these species are common: Corvus frugilegus L., 1758, Fringilla coelebs L., 1758, Emberiza citrinella L., 1758, Streptopelia orientalis Latham, 1790, Turdus pilaris L., 1758, Pica pica L., 1758. These species are present in open habitats due to reasons of foraging and gathering nest building material.

The number of cavity nesters varies across the natural zones. The biggest number is registered in the middle forest-steppe subzone (14 species) and the lowest (1 species - Cyanistes cyanus Pallas, 1770) in subtaiga and southern taiga (Fig. 2a). In all the studied habitats, meadows with groves feature the maximum number of cavity nesting birds (12 species); marshy meadows and fields - the minimum ( 1 species each).

Omnivores and facultative carnivores dominate in all subzones. The maximum number of this groups' species was noticed in the open habitats of northern forest-steppe subzone (46 species $-46.1 \%)$. In the forest steppe, their proportion is also high - 41.8\% (35 species). In the northern direction, the proportion of this group's species goes down gradually and significantly (Fig. 2). Insectivorous birds subdominate. The maximum number of this group is registered in the northern forest steppe - 33 species $(31.7 \%)$ and a slightly lower number in the middle forest steppe (24.4\%).

In the boreal subzones, the number of insectivore species decreases to 10 in subtaiga and to 8 in southern taiga, but their unit weight in communities goes up to 33.3 and $29.6 \%$, respectively.

In all subzones' habitats, there is an equal number of phytivorous and granivorous birds species (7 each), although the proportion of this group increases when moving North $(8.1 \%$ in middle forest steppe; $6.7 \%$ in northern forest steppe; $23.3 \%$ in subtaiga; $25.9 \%$ in southern taiga).

The maximum number of predator and ichthyophagous bird species is registered in the open habitats of middle forest-steppe subzone - 22 species $(25.5 \%)$ and of northern forest steppe - 16 species (15.3\%). In the subzones of subtaiga and southern taiga, there were only five and six species of this group registered, respectively; however, their unit weight is high (16.6\% in subtaiga, $33.3 \%$ in southern taiga) (Fig. 2a).

In all the open habitats, except for pastures and fields, omnivores and facultative carnivores dominate by the number of species (marshy meadows (MM) $-41.8 \%$; meadows with groves (MwG) - 36.6\%; river meadows (RM) - 46.4\%; abandoned fields (AF) - 48.4\%; salt meadows (SM) - 35.2\%). In the fields and grazing and salt meadows, the group of insectivorous birds dominates $-36.3 \%, 46.6 \%$ and $41.2 \%$, respectively. In the rest of the habitats, the insectivorous birds subdominate ( $\mathrm{MM}-21.8 \%$; $\mathrm{MwG}-29.54 \%$; RM - 26.78\%; AF - 28.12\%).

The group of phytivorous and granivorous birds is represented by a small number of species. Their maximum number is registered in the abandoned fields - six species (9.3\%): Anser anser L., 1758 (mean abundance of $0.5 \mathrm{sp} . / \mathrm{km}^{2}$ ), Columba livia Gmelin, 1789 (2.7 sp./ $\left./ \mathrm{km}^{2}\right)$, C. oenas L., 1758 (0.8 sp. $\left./ \mathrm{km}^{2}\right)$, C. palumbus L., 1758 (3.2 sp./ $\left./ \mathrm{km}^{2}\right)$, Streptopelia orientalis (1.14 sp./ $\left.\mathrm{km}^{2}\right)$, S. turtur L., $1758\left(15.14 \mathrm{sp} . / \mathrm{km}^{2}\right)$, with minimum on the pastures - two species ( $8 \%)$. In the rest of habitats, their proportion is comparable: pastures (P) $-9.09 \%, \mathrm{MM}-9.1 \%$; $\mathrm{MwG}-$ $11.3 \%$; RM - 8.9\%; SM - 9.8\%.

Carnivorous and ichthyophagous birds are most numerous in the marshy meadows - 15 species, 27.2\%: Accipiter nisus L., 1758 (0.14 sp. $\left./ \mathrm{km}^{2}\right)$, Aquila clanga Pallas, 1811 (0.04 sp. $\left./ \mathrm{km}^{2}\right)$, Ardea cinerea L., 1758 (4.4 sp./ $\left.\mathrm{km}^{2}\right)$, Asio flammeus Pontoppidan, 1763 (3.29 sp./ $\left./ \mathrm{km}^{2}\right)$, Botaurus stellaris L., 1758 (1.43 sp. $\left./ \mathrm{km}^{2}\right)$, Buteo buteo L., 1758 (0.4 sp. $\left./ \mathrm{km}^{2}\right)$, Chlidonias leucopterus Temminck, 1815 (5.43 sp. $\left./ \mathrm{km}^{2}\right)$, Ch. niger L., 1758 (16.0 sp. $\left./ \mathrm{km}^{2}\right)$, Circus aeruginosus L., 1758 (6.0 sp. $\left./ \mathrm{km}^{2}\right)$, Falco subbuteo L., $1758\left(0.57 \mathrm{sp} . / \mathrm{km}^{2}\right)$, F. tinnunculus L., 1758 (0.86 sp./km²), Grus grus L., 1758 (1.14 sp. $\left./ \mathrm{km}^{2}\right)$, Lanius excubitor L., 1758 (2.5 sp./ $\mathrm{km}^{2}$ ), Milvus migrans Boddaert, 1783 (1.14 sp./ $\left./ \mathrm{km}^{2}\right)$, Sterna hirundo L., 1758 (3.29 sp./km²). The proportion of this group in the other types of habitats is as follows: in the fields $(\mathrm{F})-22.7 \%$, in the grazing meadows $-20.8 \%$, in the meadows with groves $-19.2 \%$, in the abandoned fields $-14.06 \%$ and in the salt meadows $-13.7 \%$ (Fig. 2b).

The dominance diversity curve (species significance) of fields' ornithocenoses shows a minimal level of biodiversity (Fig. 3).

The species significance curves for marshy, salt meadows and abandoned fields are of a considerable length, which is characteristic of a great amount of regular and low-numbered species. At the same time, in these communities, the abundance of certain species in a series ranged according to their relative abundance changes more drastically than in the river meadows habitats. This is indicative of a lower resource capacity of the habitat. A still lower capacity is characteristic of grazing meadows and fields; their plots end at ranks 23 and 22, respectively, and show a steeper change in the number of each species, in compliance with MacArthur's broken stick model, attesting to a greater differentiation of ecological niches of different species (Fig. 3) (Magurran, 2004; McIntosh, 1967).

The steepest and longest plot is the one of the river meadows. The most numerous order in the river meadows is Charadriidae order; 13 species of it are common: Vanellus vanellus (16.0 $\left.\mathrm{sp} . / \mathrm{km}^{2}\right)$; Tringa totanus (7.71 sp. $\left./ \mathrm{km}^{2}\right)$; Larus ridibundus L., 1766 (6.57 sp. $\left./ \mathrm{km}^{2}\right)$; Limosa limosa (6.53 sp. $\left./ \mathrm{km}^{2}\right)$; Tringa stagnatilis Bechstein, 1803 (6.5 sp./ $\left.\mathrm{km}^{2}\right)$; Haematopus ostralegus L., $1758\left(4.43 \mathrm{sp} . / \mathrm{km}^{2}\right)$; Calidris minuta Leisler, $1812\left(3.29 \mathrm{sp} . / \mathrm{km}^{2}\right)$; Larus minutus Pallas, 1776 (3.1 sp./ $\left./ \mathrm{km}^{2}\right)$; Sterna hirundo (2.9 sp./ $\left.\mathrm{km}^{2}\right)$; Tringa glareola L., 1758 (2.4 sp./ $\left./ \mathrm{km}^{2}\right)$; Gallinago gallinago L., 1758 (1.13 sp./km²); Larus canus L., 1758 (1.13 sp. $\left./ \mathrm{km}^{2}\right) ;$ Xenus cinereus Güldenstädt, 1775 (1.1 sp./ $\left.\mathrm{km}^{2}\right)$.

A significantly greater index of species richness (almost twice as high as that for the fields and pastures) is characteristic of the abandoned fields (the difference is significant with $\mathrm{p} \leq 0.001$ ) (Table 2).

The maximum values of Shannon diversity index, increasing the weight of low-numbered species, mark ornithocenoses of 

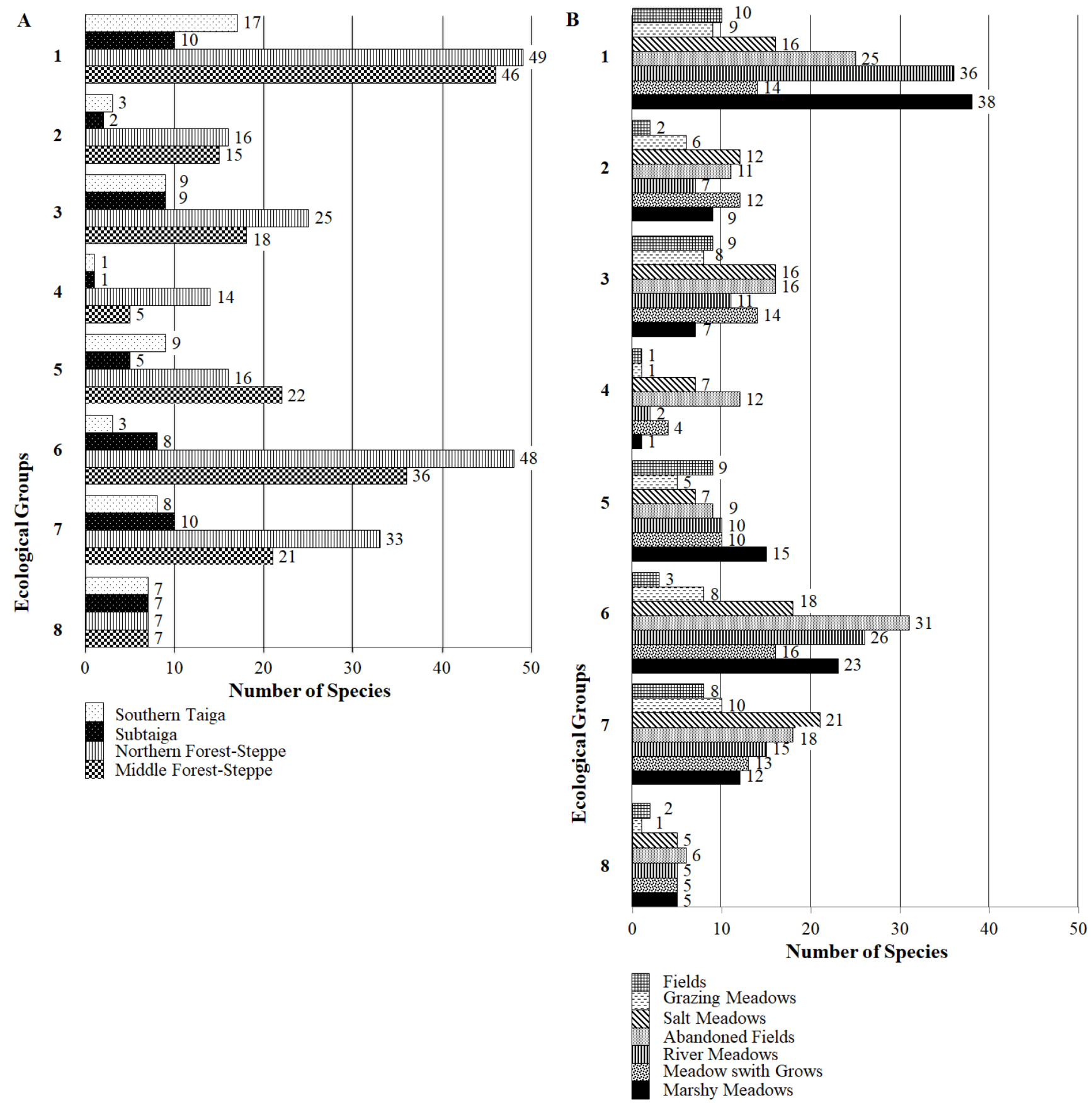

Fig. 2. The ecological structure of Ishim River region open habitats' avifauna, eating and nesting habits: A - in relation to the nature zone; $\mathrm{B}$ - in relation to the habitat; ecological groups: 1 - ground-nesting birds; 2 - bush-nesting birds; 3 - crown-nesting birds; 4 - cavity-nesting birds; 5 - carnivorous and ichthyophagous birds; 6 - omnivores and facultative carnivores; 7 - insectivores; 8 - phytivores.

river meadows (Table 2); it is significantly higher than in other types of habitats (with $\mathrm{p} \leq 0.001$ ). The lowest-numbered species of river meadows that made the biggest contribution to Shannon diversity index are ground-nesting birds: Gallinago gallinago (5.1 $\mathrm{sp} . / \mathrm{km}^{2}$, their share in total bird abundance in the corresponding habitat is $0.21 \%)$, Sterna hirundo $\left(3.1 \mathrm{sp} . / \mathrm{km}^{2}, 0.12 \%\right)$, Locustella naevia Boddaert, 1783 (1.1 sp. $\left./ \mathrm{km}^{2}, 0.04 \%\right)$; low- and groundnesting species Tringa glareola (3.43 sp. $/ \mathrm{km}^{2}, 0.14 \%$ ); high-nest- ing species Aquila clanga (1.14 sp./ $\left./ \mathrm{km}^{2}, 0.05 \%\right)$; ground- and high-nesting species Buteo lagopus Pontoppidan, 1763 (0.61 sp./ $\left.\mathrm{km}^{2}, 0.02 \%\right)$.

The maximum value of Simpson's diversity index, adding more weight to more numerous species, is characteristic of marshy meadows (Table 2). In this type of habitats, most numerous species are limnophilous birds: ground- and low-nesting: Emberiza schoeniclus L., 1758 (17.71 sp./ $\left.\mathrm{km}^{2}, 4.0 \%\right)$, Acroceph- 

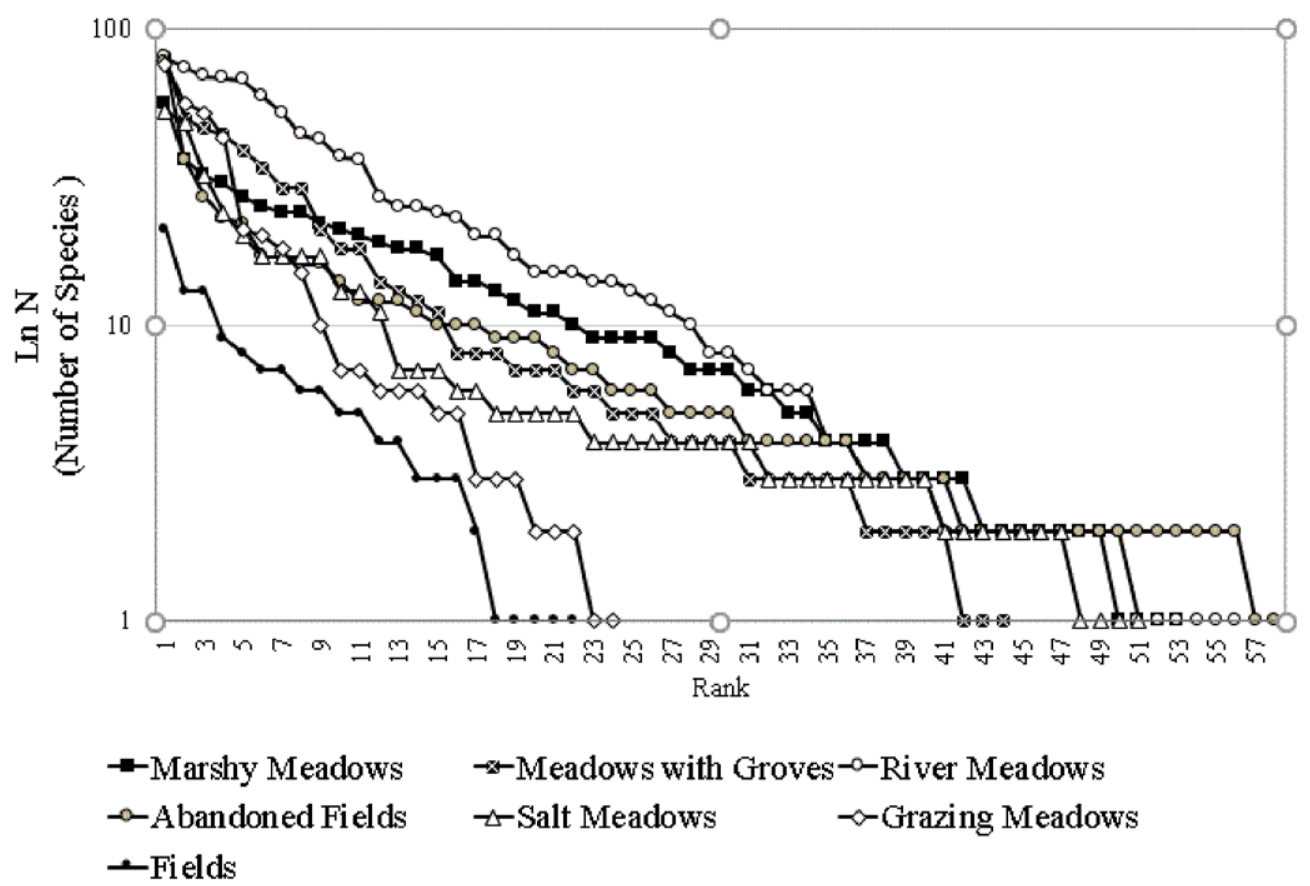

Fig. 3. Dominance/diversity plots for Russian Ishim River region open habitats ornithocenoses.

alus schoenobaenus L., 1758 (15.71 sp./ $\left./ \mathrm{km}^{2}, 3.8 \%\right)$, Anas platyrhynchos L., 1758 (15.71 sp./km², 3.8\%), A. querquedula L., 1758 (14.1 sp. $/ \mathrm{km}^{2}, 3.8 \%$ ), Chlidonias niger (13.9 sp. $/ \mathrm{km}^{2}, 3.8 \%$ ), Larus minutus (12.57 sp. $\left./ \mathrm{km}^{2}, 3.1 \%\right)$, L. ridibundus $\left(9.7 \mathrm{sp} . / \mathrm{km}^{2}, 3.0 \%\right)$, Acrocephalus agricola Jerdon, 1845 (5.43 sp./ $\left.\mathrm{km}^{2}, 2.2 \%\right)$; campophilous: ground-nesting and low-nesting species Motacilla citreola $\left(9.5 \mathrm{sp} . / \mathrm{km}^{2}, 2.9 \%\right)$ and Saxicola torquata $\left(8.57 \mathrm{sp} . / \mathrm{km}^{2}\right.$, $2.5 \%)$.

Comparatively high Simpson's diversity index values are characteristic of ornithocenoses meadows with groves (Table 2). Campophilous and dendrophilous birds are regular on the meadows with groves; the former arethe following ground- and low-nesting species: Alauda arvensis (19.86 sp. $/ \mathrm{km}^{2}, 4.4 \%$ ), Motacilla flava (17.1 sp./ $\left.\mathrm{km}^{2}, 3.7 \%\right)$, Locustella naevia $\left(9.57 \mathrm{sp} . / \mathrm{km}^{2}\right.$, $2.9 \%)$, Motacilla citreola (8.7 sp./ $\left.\mathrm{km}^{2}, 2.2 \%\right)$, Saxicola ruberta (5.56 sp. $\left./ \mathrm{km}^{2}, 1.9 \%\right)$, S. torquata $\left(4.47 \mathrm{sp} . / \mathrm{km}^{2}, 1.6 \%\right)$; and the latter are the following high- and mid-canopy nesting species: Emberiza citrinella (21.43 sp./ $\left./ \mathrm{km}^{2}, 7.4 \%\right)$, Fringilla coelebs (19.6 sp./ $\left.\mathrm{km}^{2}, 4.42 \%\right)$, Turdus pilaris (12.29 sp./ $\left.\mathrm{km}^{2}, 3.7 \%\right)$ and Carduelis carduelis (11.99 sp. $\left./ \mathrm{km}^{2}, 3.2 \%\right)$. The presence of the forest species is due to the birds living in woodland on the fringes of fields searching these areas for food. The registered higher values of Simpson's diversity index in the ornithocenoses of marshy meadows and meadows with groves are statistically significant (with $\mathrm{p} \leq 0.01$ and $\mathrm{p} \leq 0.001$ ).

The river meadows had the highest Pielou evenness index (between ornithocenoses of all types of habitats, the difference is significant with $\mathrm{p} \leq 0.001)$. The common species of the river meadows are Saxicola torquata (16 sp./ $\left.\mathrm{km}^{2}, 4.4 \%\right)$, Vanellus vanellus (16 sp./ $\left.\mathrm{km}^{2}, 4.4 \%\right)$, Pica pica (11.1 sp. $\left./ \mathrm{km}^{2}, 5.03 \%\right)$ and Corvus frugilegus (6.57 sp./ $\left./ \mathrm{km}^{2}, 2.5 \%\right)$.
Significantly higher indices of resistant, elastic and general sustainability are characteristic of river meadows' ornithocenoses: (the difference is significant with $\mathrm{p} \leq 0.01$ and $\mathrm{p} \leq 0.001$ ). Among the transformed habitats, fields ornithocenoses have a significantly higher value of resistant sustainability index (with $\mathrm{p} \leq 0.01$ and $\mathrm{p} \leq 0.001$ ), and abandoned fields ornithocenoses have higher values of elastic and general sustainability (the differences are significant with $\mathrm{p} \leq 0.01$ and $\mathrm{p} \leq 0.001$ ).

The analysis of similarity of open habitats avifauna of different natural zones (subzones) using Jaccard index (Ij) showed that the most similar ornithocenoses are those of adjacent zones: the middle and the northern forest steppe; the northern forest steppe and the subtaiga (Fig. 4).

The analysis of Whittaker index (Iw) showed that maximum diversity (heterogeneity) is characteristic of ornithocenoses of southern taiga habitats (Fig. 4).

Comparison of avifaunae of the habitats having the same names but coming from different natural zones and subzones showed that the most similar are river meadows of the middle and the northern forest steppe $(\mathrm{Ij}=0.91)$ with 55 species in common; the most diverse are meadows with groves of the northern forest steppe and the southern taiga $(\mathrm{Ij}=0.4)$ with 18 species in common.

When comparing ornithocenoses of different habitats, the maximum similarity in terms of fauna is observed between the ornithocenoses of meadows with groves and fields $(\mathrm{Ij}=0.91)$ with 15 species in common, among which the following species are regular and numerous: Alauda arvensis, Anthus trivialis, Calcarius lapponicus, Corvus frugilegus, Motacilla citreola and Streptopelia orientalis. The ornithocenoses of marshy and river meadows are very similar $(\mathrm{Ij}=0.9)$, with 19 species in common, 


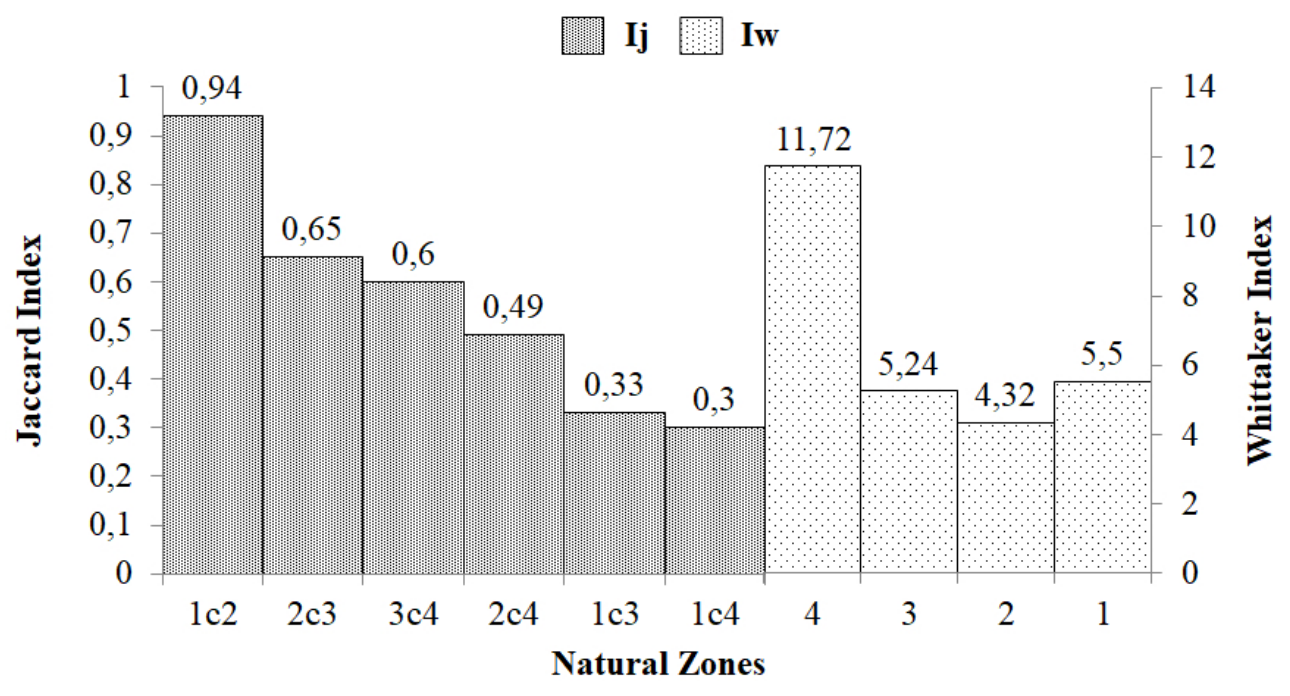

Fig. 4. Jaccard similarity coefficient and Whittaker diversity index for ornithocenoses of open habitats of different natural zones (subzones) of Russian Ishim River region: 1 - middle forest steppe; 2 - northern forest steppe; 3 - subtaiga; 4 - southern taiga; $c$ - samples compared.

among which the following species are regular and numerous: Buteo buteo, Carduelis carduelis, Circus cyaneus L., 1766, Coturnix coturnix, Emberiza citrinella, E. schoeniclus, Falco tinnunculus, Larus ridibundus, Limosa limosa and Saxicola ruberta.

There are 13 species in common in the avifaunae of meadows with groves and abandoned fields $(\mathrm{Ij}=0.8)$, including the following regular and numerous species: Acanthis flammea L., 1758, Alauda arvensis, Anthus campestris, Cannabina cannabina, Emberiza citrinella, Falco tinnunculus, Fringilla coelebs, Grus grus, Milvus migrans and Motacilla flava. There are 10 species in common in the avifaunae of river meadows and abandoned fields $(\mathrm{Ij}=0.71)$, including the following regular and numerous species: Circus cyaneus, Coturnix coturnix, Emberiza citrinella, E. schoeniclus, Motacilla flava, Saxicola ruberta and S. torquata. There are 11 species in common in the avifaunae of meadows with groves and salt meadows $(\mathrm{Ij}=0.71)$, including the following common/usual species: Alauda arvensis, Asio flammeus, Motacilla citreola, Saxicola ruberta and S. torquata. The lowest similarity index is characteristic of avifaunae of marshy meadows and fields $(\mathrm{Ij}=0.3)$, only three species being regular: Asio flammeus, Grus grus and Saxicola ruberta (Table 3).

\section{Discussion}

The open habitats of the Russian Ishim River region have 24.7\% of the total number of birds of the West Siberian Plain (Ravkin et al., 2000), 25.4\% of the total number of birds of the Tyumen Region (https://www.utmn.ru) and $36.8 \%$ of the total number of birds registered by the authors in 2014-2017 in the Ishim River region. The total number of species increases from the taiga zone to the forest-steppe zone, peaking in the northern forest steppe. The taxonomic and ecological structure of ornithocomplexes complies with the landscape and biotope peculiarities of the habitats.
The ornithocomplexes of forest-steppe zone (mainly the subzone of northern forest steppe) show the maximum species and structure diversity. It is in line with Ravkin and Bogomolova (2018) that pointed out that $54 \%$ dispersion of birds population in terms of diversity and $50 \%$ of dispersion in terms of abundance may be explained by the change in the amount of the heat in different latitudes; it was also shown that there is a tendency of Shennon's diversity index $(H)$ to grow from the arctic type of birds population to the forest middle-taiga and subtaiga types (the latter includes ornithocomplexes of the majority of habitats of the forest-steppe zone) and a tendency of $H$ to decrease in the steppe type of population (that encompasses the ornithocomplexes of agricultural lands and salt meadows of the forest steppe). The maximum number of bird species in the northern forest-steppe subzone on the border of taiga and forest-steppe zones is congruent with Parfenova et al. (2004) data, the research showed a case of the Middle Siberia vegetation cover when the climatic ideal conditions for the maximum biodiversity are found in the subtaiga-forest-steppe zone and are characterized by a balanced ratio between heat and moisture when the dryness index is around $1.0(0.8-1.2)$ with an adequate amount of heat around $30-35 \mathrm{kkal} /\left(\mathrm{cm}^{2} \cdot\right.$ year $)$.

Among all types of habitats, the avifauna of abandoned fields has the most diverse taxonomic structure, while that of the pastures and fields is least diverse. The indices of total birds abundance, diversity and sustainability change proportionally. Comparatively high values of diversity index, elastic and general sustainability of abandoned fields' ornithocenoses as compared to the communities of fields and pastures may be explained by an added complexity of plant communities and by higher levels of habitats' resource capacity undergoing secondary succession. A significantly higher value of resistant sustainability of fields ornithocenoses as compared to those of pastures and abandoned fields is in line with the idea of a higher resistant sustainability 
Table 3. The distribution of Jaccard indices for open habitats ornithocenoses of Ishim River region, Russian part (Jaccard, 1901).

\begin{tabular}{|c|c|c|c|c|c|c|c|}
\hline & $\begin{array}{c}\text { Marshy } \\
\text { meadows }\end{array}$ & $\begin{array}{c}\text { Meadows with } \\
\text { groves }\end{array}$ & River meadows & $\begin{array}{c}\text { Abandoned } \\
\text { fields }\end{array}$ & Salt meadows & Pastures & Fields \\
\hline $\mathbf{1}$ & 1 & 0.36 & 0.90 & 0.51 & 0.33 & 0.33 & 0.30 \\
\hline $\mathbf{2}$ & 0.36 & 1 & 0.79 & 0.80 & 0.71 & 0.60 & 0.91 \\
\hline $\mathbf{3}$ & 0.90 & 0.79 & 1 & 0.71 & 0.65 & 0.65 & 0.49 \\
\hline $\mathbf{4}$ & 0.51 & 0.80 & 0.71 & 1 & 0.56 & 0.46 & 0.47 \\
\hline $\mathbf{5}$ & 0.33 & 0.71 & 0.65 & 0.56 & 1 & 0.58 & 0.68 \\
\hline $\mathbf{6}$ & 0.33 & 0.60 & 0.65 & 0.46 & 0.58 & 1 & 0.60 \\
\hline $\mathbf{7}$ & 0.30 & 0.91 & 0.49 & 0.47 & 0.68 & 0.60 & 1 \\
\hline
\end{tabular}

Notes: 1 - marshy meadows; 2 - meadows with groves; 3 - river meadows; 4 - abandoned fields; 5 - salt meadows; 6 - pastures; 7 - fields.

of disturbed communities as compared to the natural ones, as shown by Gashev $(2000,2001)$ and Gashev et al. (2015) in case of small mammals.

In all the undisturbed habitats, the river meadows' highest values of diversity and abundance may be accounted for mainly by their higher forage capacity due to the highest invertebrata biomass (Batzer, Wissinger, 1996; Adis, Junk, 2002; Stagliano et al., 1998), as the invertebrates attract both campophilous (28.3\%) and limnophilous (48.42\%) birds. The mean value of Shennon's diversity index for river meadows is close to the maximum for the majority of communities described in literature $(H=4.5)$. High diversity and evenness underlie the maximum values of river meadows ornithocenoses' sustainability indices.

Statistically significant differences in abundance, diversity and sustainability indices between the ornithocenoses of different types of the undisturbed meadows (river, marshy, salt meadows and meadows with groves) are consistent with conclusions of Ravkin et al. (2016) that showed there is significant influence of water supply on the territory (this factor accounts for $9 \%$ of bird population dispersion in terms of diversity and abundance), humification ( $8 \%$ of dispersion), inundation and high water regime ( $8 \%$ of dispersion), and area under forest (18\% of dispersion).

The fact that the avifauna of the adjacent zones is most similar (middle and northern forest steppe; northern forest steppe and subtaiga) may be accounted for by a similarity in naturalclimatic complexes, including similar plant communities of the contiguous subzones, especially forest-steppe habitats that lie within one natural zone.

A high fauna similarity of river meadows' ornithocomplexes in the middle and northern forest steppes may be accounted for by the fact that the river meadows as intrazone habitats are very similar from the point of view of the living conditions, even more so within one and the same natural-climatic zone and, consequently, they have similar flora and fauna. On the other hand, considerable differences of avifaunae of meadows with groves in the northern forest steppe and the southern taiga may be explained by the fact that the qualitative composition of bird population of this type of habitat depends on the area, flora composition and vegetation structure of the neighbouring forestland wherefrom forest-dwelling species come to open habitats. The migrants' composition and permeation intensity vary widely depending on the natural zone. For example, the biggest number of dendrophilous species - 28- are registered exactly in the south- ern taiga meadows with groves; in the other subzones, they are far fewer in number: 16 in subtaiga and 12 in each of northern and middle forest steppes.

The level of faunal diversity and similarity between the ornithocenoses of different habitats is determined by the level of their biotope similarity and heterogeneity.

\section{Conclusion}

In the course of investigation, 95 bird species from 72 genera and 10 orders were registered in the open habitats of the Russian part of the Ishim River region, with the Passeriformes order dominating. The taxonomic composition of avifauna is congruent with habitats' biotopical characteristics. The birds' taxonomic diversity is a direct function of heterogeneity of the habitats.

The ecological structure of the investigated habitats' avifauna corresponds to their biotopical characteristics: in all types of habitats, low- and ground-nesting birds predominate, so do omnivores and facultative carnivores. The unit weight of the other ecological groups varies depending on the specific biotopic conditions, including those of the natural-climatic zone.

Open habitats of forest-steppe zone, the northern foreststeppe subzone, show maximum birds species diversity and structural diversity, which is in accord with the climatic optimum of biodiversity.

Among the natural habitats under consideration, the maximum total abundance of birds, highest species diversity within the habitat ( $\alpha$-diversity) and sustainability are characteristic of ornithocenoses of river meadows, mainly owing to low-numbered species and higher evenness values.

Among the disturbed habitats, the maximum values of total abundance, species diversity, Shannon diversity index, Pielou's evenness index, elastic and general sustainability values and the minimal index of diversity are characteristic of ornithocenoses of abandoned fields, due to amplification in vegetation community structure and an increase in habitat's resource capacity in the process of secondary succession.

The most similar avifaunae are those of open habitats of contiguous subzones - the middle and the northern forest steppes - which stem from their natural and historical unity. The most heterogeneous ornithocenoses are those of southern taiga open habitats. This fact is explained by an increase in the variability of forest birds species share in ornithocenoses ecological structure 
due to an increase in the area and diversity of forest habitats, mixed parvifoliate and pine-parvifoliate forests.

The level of faunal similarity between ornitocenoses of the same type of habitats from different physico-geographical zones and different types of habitats from one and the same zone is determined by the level of their biotope similarity and diversity.

\section{References}

Adis, J. \& Junk W.J. (2002). Terrestrial invertebrates inhabiting lowland river floodplains of Central Amazonia and Central Europe: a review. Freshw. Biol., 47, 711-731. DOI: 10.1046/j.1365-2427.2002.00892.x.

Allan, E., Manning, P., Prati, D., Grassein, F., Alt, F., Binkenstein, J., Blaser, S., Blüthgen, N., Hölzel, N., Klaus, V.H., Kleinebecker, T., Morris E-K., Oelmann, Y., Renner, S.C., Rillig, M.C., Schäfer, M., Schloter, M., Schmitt, B., Schöning, I., Schrumpf, M., Solly, E., Sorkau, E., Steckel, J., Steffen-Dewenter, I., Stempfhuber, B., Trumbore, S., Weiner, C.N., Weisser, W.W., Werner, W., Westphal, C., Wilcke, W. \& Fischer M. (2015) Land use intensification alters ecosystem multifunctionality via loss of biodiversity and changes to functional composition. Ecol. Lett., 18, 834-843. DOI: 10.1111/ele.12469.

Batzer, D.P. \& Wissinger S.A. (1996). Ecology of insect communities in nontidal wetlands. Annu. Rev. Entomol., 41, 75-100. DOI

Blinkova, O. \& Shupova T. (2017). Bird communities and vegetation composition in the urban forest ecosystem: correlations and comparisons of diversity indices. Ekológia (Bratislava), 36(4), 366-387. DOI: 10.1515/ eko-2017-0029.

Bradbury, R.B., Wilson, J.D., Moorcroft, D., Morris, A.J. \& Perkins A.J (2003). Habitat and weather are weak correlates of nesting condition and growth rates of four UK farmland passerines. Ibis, 145, 295- 306. DOI: 10.1046/j.1474-919X.2003.00142.x.

Brinkert, A., Hölzel, N., Sidorova, T.V. \& Kamp J. (2016). Spontaneous steppe restoration on abandoned cropland in Kazakhstan: grazing affects successional pathways. Biodivers. Conserv., 25(12), 2543-2561. DOI 10.1007/s10531-015-1020-7.

Donald, P.F., Green, R.E. \& Heath M.F. (2001). Agricultiral intensification and the collapse of Europe's farmland bird populations. Proc. R. Soc. Lond., 268, 25-29. DOI: 10.1098/rspb.2000.1325.

Gashev, S.N. (2000). The Mammals in system of the ecological monitoring (on example of the Tyumen region). Tyumen: Tyumen State University.

Gashev, S.N. (2001). Elastic stability of ecological systems (in Russian). Siberian Journal of Ecology, 8(5), 645-650.

Gashev, S.N. (2012). Patent of Russia (in Russian). Patent No. 2012620405. Ornithologists' Workplace.

Gashev, S.N. (2014). Practical application of the technique of the route accounting of birds with an unlimited width of the registration strip (in Russian). Ecological Monitoring and Biodiversity, 2(9), 58-61.

Gashev, S.N., Bykova, E.A. \& Levykh A.Yu. (2015). Resilience of small mammalian urbenoza communities in various natural zones (in Russian) Proceedings of the Samara Scientific Centre of the Russian Academy of Sciences, 17(6), 14-18.

Jaccard, P. (1901). Distribution de la flore alpine dans le Bassin des Dranses et dans quelques regions voisines (in France). Bull. Soc. Vaud. Sci. Nat., 37, 241-272.

Kamp, J., Koshkin, M., Bragina, T., Katzner, T., Milner-Gulland, E., Schreiber, D., Sheldon, R., Shmalenko, A., Smelansky, I. \& Terraube J. (2016a). Persistent and novel threats to the biodiversity of Kazakhstan's steppes and semi-deserts. Biodivers. Conserv., 25(12), 2521-2541. DOI: 10.1007/ s10531-016-1083-0.

Kamp, J., Oppel, S., Heldbjerg, H., Nyegaard, T. \& Donald P.F. (2016b). Unstructured citizen science data fail to detect long-term population declines of common birds in Denmark. Divers. Distrib., 22(10), 1024-1035 DOI: $10.1111 /$ ddi. 12463 .
Levykh, A.Yu. \& Panin V.V. (2019). Species composition and community structure of small mammals in Parapolsky Dol (Koryak State Nature Reserve, Kamchatka). Nature Conservation Research, 4(3), 1-12. DOI 10.24189/ncr.2019.026.

Magurran, A.E. (2004). Measuring biological diversity. Oxford: Blackwell Publishing.

McIntosh, R.P. (1967). An index of diversity and the relation of certain concepts to diversity. Ecology, 48(3), 392-404. DOI: 10.2307/1932674.

Mordkovich, V.G. (2012). West Siberian forest-steppe as an agglomeration of biodiversity, universal biom and reserve of forthcoming biogeographical rearrangements (in Russian). Siberian Ecological Journal, 1, 27-34.

Pain, D.J. \& Pienkowski M.W. (1996). Farming and birds in Europe: The common agricultural policy and its implications for birds conservation. London: Academic Press.

Parfenova, E.I., Tchebakova, N.M. \& Vlasenko V.I. (2004). Relationships between climatic factors and biodiversity of vegetation cover in Central Siberia at different levels of organization (in Russian). Siberian Journal of Ecology, 11(5), 725-734.

Ravkin, Yu.S. (1967). To the methods of forest landscape bird census (in Russian). In A.A. Maximov (Eds.), The nature of tick-borne encephalitis nidi in the Altai (North-Eastern part) (pp. 66-75). Novosibirsk: Nauka, Siberian Branch.

Ravkin, Y.S. \& Bogomolova I.N. (2018). Ecological organization of the spatiotypological diversity of Amphibian, Reptile, and Small Mammal Communities in the West Siberian Plain (in Russian). Biol. Bull., 45(10), 1241-1249.

Ravkin, Y.S., Bogomolova, I.N., Tsybulin, S.M., Zheleznova, T.K., Toropov, K.V., Vartapetov, L.G., Milovidov, S.P., Yudkin, V.A., Zhukov, V.S., Gureev, S.P., Pokrovskaya, I.V., Kasibekov, E.S., Ananin, A.A. \& Bochkareva E.N. (2016). Spatial-typological heterogeneity and environmental organization of the summer population of birds in the Middle Region of Northern Eurasia. Contemporary Problems of Ecology, 9(1), 86-97. DOI: $10.1134 /$ S1995425516010121.

Ravkin, Yu.S., Yudkin, V.F., Zhukov, V.S., Vartapetov, L.G., Milovidov, S.P., Toropov, K.V., Pokrovskaya, L.V., Tsybulin, S.M., Adam, A.M., Fomin, B.N., Ananin, A.A., Blinova, T.K., Solovyev, S.A., Shor, E.L., Vakhrushev, A.A., Anufriev, V.M., Kozlenko, A.B., Tertitsky, G.M. \& Ravkin E.S (2000). Classification of birds of the West Siberian Plain by similarity of distribution (in Russian). Siberian Journal of Ecology, 7(3), 337-345.

Ruzskij, M.D. (1897). A faunistic outline of the Southern Part of Tobolsk Governorate. A report of 1896 zoologic research done for Tobolsk Governor (in Russian). Tobolsk: Tobolsk Governance Museum Annual.

Soloviev, S.A. (2012). Birds of the Tobolo-Irtyshskaya forest steppe: Western Siberia and Northern Caucasus. Spacial structure and organization of the population. Vol. 1 (in Russian). Novosibirsk: Publishing House SB RAS.

Soloviev, S.A., Zheleznova, T.K., Blinov, V.N. \& Vertapetov L.G. (2016). The agricultural influence on the bird populations of forest steppe and steppe of South-Western part of Western Siberia and Northern Kazakhstan (in Russian). In II International Ornithological Conference: Birds and agriculture: current state, challenges and prospects (pp. 283-287). 17-19 September 2018 Moscow.

Stagliano, D.M., Benke, A.C. \& Anderson D.H. (1998). Emergence of aquatic insects from 2 habitats in a small wetland of the southeastern USA: temporal patterns of numbers and biomass. J. North Am. Benthol. Soc., 17, 37-53. DOI: $10.2307 / 1468050$.

Stepanyan, L.S. (2003). Conspectus of the ornithological fauna of Russia and adjacent territories (within the boarders of the USSR as a historic region) (in Russian). Moscow: Akademkniga Press.

Tyumen Region Birds List (2020). https://www.utmn.ru/upload/medialibrary/fa2/Список\%20птиц.pdf

Whittaker, R.H. (1964). Patterns in the balance of nature. London: Academic Press. 